\title{
Production and characterization of a highly pure RNA polymerase holoenzyme from Mycobacterium tuberculosis
}

Omar Herrera-Asmat $^{\text {ab }}$, Lucyna Lubkowska ${ }^{c}$, Mikhail Kashlev ${ }^{c}$, Carlos J. Bustamante ${ }^{\mathrm{d}^{*}}$, Daniel G. Guerra $^{\mathrm{b}^{* *}}$, Maria L. Kireeva $\mathrm{a}^{\mathrm{c} * *}$

a Jason Choy laboratory of Single Molecule Biophysics, Department of Molecular and Cell Biology, University of California, Berkeley, CA 94720 USA

${ }^{\mathrm{b}}$ Laboratorio de Moléculas Individuales, Facultad de Ciencias y Filosofía, Universidad Peruana Cayetano Heredia, Av. Honorio Delgado 430, San Martin de Porras, Lima-31, Perú

${ }^{\mathrm{c}}$ NCI Center for Cancer Research, Frederick, MD 21702, USA

dJason Choy laboratory of Single Molecule Biophysics, Department of Molecular and Cell Biology, Department of Physics and Department of Chemistry, Kavli Energy Nanoscience Institute, Howard Hughes Medical Institute, University of California, Berkeley, CA 94720, USA

* Corresponding author: carlosb@berkeley.edu

** Corresponding author: daniel.guerra@upch.pe

*** Corresponding author: kireevam@mail.nih.gov

Keywords:

Promoter initiation; open complex; elongation complex assembly 


\begin{abstract}
Recent publications have shown that active RNA polymerase (RNAP) from Mycobacterium tuberculosis (MtbRNAP) can be produced by expressing all four subunits in a single recombinant Escherichia coli strain [1-3]. By reducing the number of plasmids and changing the codon usage of the Mtb genes in the co-expression system published by Banerjee et. al [1], we present a simplified, detailed and reproducible protocol for the purification of recombinant MtbRNAP containing the $\omega$ subunit. Moreover, we describe the formation of ternary elongation complexes (TECs) with a short fluorescence-labeled RNA primer and DNA oligonucleotides, suitable for transcription elongation studies. The purification of milligram quantities of the pure and highly active holoenzyme omits ammonium sulfate or polyethylene imine precipitation steps [4] and requires only $5 \mathrm{~g}$ of wet cells. Our results indicate that subunit assemblies other than $\alpha_{2} \beta \beta^{\prime} \omega \cdot \sigma^{\mathrm{A}}$ can be separated by ion-exchange chromatography on Mono Q column and that assemblies with the wrong RNAP subunit stoichiometry lack transcriptional activity. We show that MtbRNAP TECs can be stalled by NTP substrate deprivation and chased upon the addition of missing NTP(s) without the need of any accessory proteins. Finally, we demonstrate the ability of the purified MtbRNAP to initiate transcription from a promoter and establish that its open promoter complexes are stabilized by the M. tuberculosis protein CarD.
\end{abstract}




\section{INTRODUCTION}

Bacterial RNA polymerase (RNAP) is a complex multimeric enzyme of high interest for fundamental research because of its essential role in gene expression, and for biomedical research as a target of antibiotics [5,6]. In particular, rifampin is a potent inhibitor of RNAP activity [3,7] that has allowed the development of successful short course antibiotic treatments against tuberculosis $[8,9]$. Thus, convenient protocols for the production and activity assays of Mycobacterium tuberculosis RNAP (MtbRNAP) will be essential for the development of new inhibitors and for the characterization of its polymorphic variants, particularly those linked to drug resistance [10].

A number of methods have been used for the purification of prokaryotic RNA polymerases [11]. Difficulties arise from its tendency to misfold, relatively low stability, and a tendency to form oligomers [12] which are likely to lose activity during storage (Kashlev, unpublished observation). The vast majority of biochemical studies on prokaryotic RNAP have been performed on the E. coli enzyme. However, RNAP's activity is finely tuned by regulatory DNA sequences, GC content and protein transcription factors $[13,14]$, all of which vary greatly among bacterial groups, implying that the $E$. coli enzyme might be a poor model to investigate the medically relevant aspects of gene expression in $M$. tuberculosis [15] as well as its interaction with drugs.

Purification of MtbRNAP from M. tuberculosis cultures [16] involves severe risks and costs, therefore some research groups have developed alternative sources for mycobacterial RNAP, such as M. bovis or M. smegmatis [17] which offer the advantage of growing faster than $M$.

tuberculosis and of posing no significant risk for humans. However, despite the sequence similarity of these enzymes to MtbRNAP, it is not known to what extent their biochemical properties and in vivo regulatory mechanisms differ from the MtbRNAP enzyme.

The heterologous expression of each of the MtbRNAP subunits $\left(\alpha, \beta, \beta^{\prime}, \omega\right.$, and $\left.\sigma^{\mathrm{A}}\right)$ in separate E. coli clones allowed a high yield of protein, but with low specific activity, probably due to misfolding during the reconstitution in vitro [18]; moreover, our own trials with similar protocols showed the presence of $E$. coli $\beta$ subunit in the final product, raising concerns about the formation of inter-species chimeras (data not shown). More recently, it has been shown that co-expression of all MtbRNAP subunits in a single $E$. coli clone can produce an active enzyme [3,19] that can be expressed also in high yield without the presence of chimeras [1]. This strategy has also been used in the co-expression of RNAP of $M$. bovis with the $\beta$ and $\beta$ ' subunits linked as a single peptide [2]. In general, however, until now there has been no detailed protocol to separate out the main undesirable sub-assemblies formed during the co-expression of the MtbRNAP in E. coli. 
In this work, we use two plasmids to co-express all the subunits of MtbRNAP holoenzyme in E. coli, having optimized the codon usage of the genes for their expression in this host. Using a two-step purification through a $\mathrm{Ni}^{2+}$ column and a Mono $\mathrm{Q}$ ion exchange column, we identify the $\omega$ subunit-containing MtbRNAP holoenzyme in Coomassie blue-stained gels. The purified enzyme was used to assembly ternary elongation complex (TEC) [20] carrying a fluorescein-labeled RNA $[21,22]$. Moreover, we show that the purified MtbRNAP holoenzyme is able to form initiation complexes with promoter DNA and that these are stabilized by addition of M. tuberculosis CarD.

\section{MATERIALS AND METHODS}

Strains and bacterial growth. E. coli BL21 (DE3) strain (New England Biolabs) was used for expression of the recombinant RNAP of M. tuberculosis and the transcription factor CarD. All MtbRNAP preparations produced in this work originated from the simultaneous expression of $\alpha, \beta, \beta^{\prime}$, and $\omega$ core subunits along with $\sigma^{\mathrm{A}}$. Therefore, all MtbRNAP entries below refer to the holoenzyme containing the $\sigma^{\mathrm{A}}$ subunit.

Plasmids. The sequences of $M$. tuberculosis genes $r p o A, r p o B, r p o C$, rpoD and $r p o Z$, were modified in order to optimize their codon usage for expression in E. coli and a decahistidine tag was added to the N-terminus of the $\alpha$ subunit. The corresponding DNA constructs were synthesized by GenScript and inserted in the plasmids pET Duet -1 and pACYC Duet-1 (Merck Millipore) to produce the plasmids pET-Duet-BC (carrying $r p o B$ and $r p o C$ genes) and pACYC-Duet-AZD (carrying rpoA, rpoZ and rpoD genes). Similarly, the carD gene of $M$. tuberculosis with the E. colioptimized codon usage was synthesized and inserted in pET28a plasmid using the sites NdeI and HindIII to produce plasmid pET28-His-CarD.

Protein expression. E. coli cells transformed with the plasmids pET-Duet-BC and pACYC-DuetAZD were cultured in Luria-Bertani (LB) medium supplemented with $100 \mu \mathrm{g} / \mathrm{ml}$ ampicillin (Amp) and $30 \mu \mathrm{g} / \mathrm{ml}$ chloramphenicol $(\mathrm{Cm})$ overnight at $37^{\circ} \mathrm{C}$ with $220 \mathrm{rpm}$ agitation. $5 \mathrm{ml}$ of this starter culture was used to inoculate $1 \mathrm{~L}$ of $\mathrm{LB}+\mathrm{Amp}+\mathrm{Cm}$, which was then incubated for 3-4 hours at $37^{\circ} \mathrm{C}$ to reach an optical density $\left(\mathrm{OD}_{600}\right)$ of $\sim 0.7$. The culture was then allowed to cool down for 30 $\min$ at room temperature $\left(\sim 25^{\circ} \mathrm{C}\right)$ and IPTG was added to a final concentration of $0.3 \mathrm{mM}$. The induced culture was kept at RT overnight while agitated by a magnetic stir bar (700 - $800 \mathrm{rpm})$. The cells were centrifuged $(10,000 \times \mathrm{g}$ for $15 \mathrm{~min})$ at $4{ }^{\circ} \mathrm{C}$ and washed once with cold phosphate buffer 
saline (PBS) pH $7.4\left(137 \mathrm{mM} \mathrm{NaCl}, 2.7 \mathrm{mM} \mathrm{KCl}, 10 \mathrm{mM} \mathrm{Na} 2 \mathrm{HPO}_{4}, 1.8 \mathrm{mM} \mathrm{KH}_{2} \mathrm{PO}_{4}\right)$. The pellets from three separate one liter cultures were collected and frozen at $-80^{\circ} \mathrm{C}$.

Purification of MtbRNAP. All purification procedures were carried out at $4^{\circ} \mathrm{C}$. Frozen cell pellet (5 g) was re-suspended in $30 \mathrm{ml}$ of lysis buffer (all buffer solutions are listed in Table 1), and sonicated for 4.5 minutes on ice with the power set at $45 \%$ and ON/OFF cycles of $9 \mathrm{~s}$ (Sonicator $3000 ®)$. The lysate was clarified by centrifugation at $20,000 \times \mathrm{g}$ for 30 minutes. The soluble fraction was mixed with buffer A-1000 to adjust the volume to $200 \mathrm{ml}$, and loaded at $1.0 \mathrm{ml} / \mathrm{min}$ flow rate onto a $5 \mathrm{ml}$ HisTrap ${ }^{\mathrm{TM}}$ pre-packed column (GE Healthcare), pre-equilibrated with buffer A-1000 using ÄKTA system (GE Healthcare). The column was washed with approximately $75 \mathrm{ml}$ (15 column volumes) of buffer A-1000, until a constant low absorbance at $280 \mathrm{~nm}\left(\mathrm{~A}_{280}\right)$ was reached, and with $25 \mathrm{ml}$ of buffer A-200. The flow rate was increased to $2 \mathrm{ml} / \mathrm{min}$, and a $40 \mathrm{ml}$ gradient of imidazole from 0 to $120 \mathrm{mM}$ in buffer A-200 was applied to the column to elute and discard the major contaminants. After the $\mathrm{A}_{280}$ plateau was reached, MtbRNAP was eluted with buffer A-200 supplemented with $200 \mathrm{mM}$ imidazole. Finally, the column was washed with buffer A-1000 supplemented with $400 \mathrm{mM}$ imidazole.

Four fractions containing MtbRNAP subunits were pooled and diluted with buffer TGEB to $50 \mathrm{ml}$ and loaded to a $1 \mathrm{ml}$ Mono Q 5/5 column (GE Healthcare) equilibrated with buffer TGEB at a $1 \mathrm{ml} / \mathrm{min}$ flow rate. The Mono Q column was washed with $15 \mathrm{ml}$ TGEB supplemented with 200 $\mathrm{mM} \mathrm{NaCl}$ and $15 \mathrm{ml}$ TGEB with $300 \mathrm{mM} \mathrm{NaCl}$. Then a $22 \mathrm{ml}$ linear gradient from 300 to $370 \mathrm{mM}$ $\mathrm{NaCl}$, followed by an $18 \mathrm{ml}$ gradient from 370 to $490 \mathrm{mM} \mathrm{NaCl}$, and a $20 \mathrm{ml}$ gradient from 490 to $1000 \mathrm{mM} \mathrm{NaCl}$ were consecutively applied. The eluate was collected in $1-1.3 \mathrm{ml}$ fractions.

The fractions containing the active MtbRNAP holoenzyme were pooled and concentrated in a $15 \mathrm{ml}$ Amicon $3 \mathrm{kDa}$ MWCO co (Millipore) at 3,000 $\mathrm{g}$ for 20-40 min at $4^{\circ} \mathrm{C}$. The retentate solution was diluted two-fold with a $2 \mathrm{X}$ storage buffer, concentrated again, and mixed with an equal volume of sterile glycerol. The sample was divided in $100 \mu 1$ and $10 \mu 1$ aliquots that were flash frozen by immersion in liquid nitrogen, and stored at $-80^{\circ} \mathrm{C}$.

Expression and purification of CarD from M. tuberculosis. Two one liter cultures of $E$. coli carrying pET28a-His 6 -CarD plasmid were grown in LB medium supplemented with $50 \mu \mathrm{g} / \mathrm{ml}$ kanamycin until $\mathrm{OD}_{600}$ of 0.4-0.6 was reached, and were then induced with $0.3 \mathrm{mM}$ IPTG at $25^{\circ} \mathrm{C}$ for 3 hours. The bacterial pellet was lysed in $50 \mathrm{mM}$ Tris- $\mathrm{HCl}$, pH 8.0, $250 \mathrm{mM} \mathrm{NaCl}, 1 \mathrm{mM}$ DTT and the clarified soluble fraction was loaded onto a $5 \mathrm{ml}$ HisTrap ${ }^{\mathrm{TM}}$ pre-packed column (GE Healthcare) previously equilibrated with the same buffer. The column was washed with $40 \mathrm{mM}$ 
imidazole in the same buffer and the protein elution was performed with $50 \mathrm{mM}$ Tris- $\mathrm{HCl}, \mathrm{pH} 7.6$, $150 \mathrm{mM} \mathrm{NaCl}$ containing $500 \mathrm{mM}$ imidazole. The eluted protein was additionally purified on a Superdex 200 10/300 GL column (GE Healthcare). The main peak that contained the CarD dimer was collected and dialyzed against lysis buffer containing $50 \%$ of glycerol.

Protein analyses. The cells lysates, chromatographic fractions, and purified protein preparations were analyzed in NuPAGE 4-20\% SDS protein gels resolved in MES buffer (Invitrogen). The gels were stained with Simply Blue Safe Stain (Invitrogen). Protein concentration was determined with Bradford reagent (Bio-Rad) using BSA as a standard.

Formation and walking of the TECs. The TEC assembly $[20,22,23]$ was initiated by annealing of $15 \mu \mathrm{M}$ each of 5'-fluorescein-labeled RNA to a template DNA oligonucleotide to form an RNADNA hybrid. 0.03-0.3 $\mu \mathrm{M}$ MtbRNAP was added to $0.09-3 \mu \mathrm{M}$ of the RNA-DNA hybrid and incubated in TB40 at $25^{\circ} \mathrm{C}$ for $10 \mathrm{~min}$. In most experiments a DNA oligonucleotide complementary to the template DNA strand was added to this pre-formed single-strand DNA complex at a 2-fold molar excess over the RNA-DNA hybrid, and incubated for $10 \mathrm{~min}$. The TECs stalled downstream from the assembly site were obtained by addition of a $20 \mu \mathrm{M}$ NTP subset containing only three of the four NTPs for $10 \mathrm{~min}$. RNA elongation to form the run-off product was re-started from the stall site by adding all four NTPs. Transcription was stopped by addition of the EDTA- and ureacontaining gel loading buffer. The RNA was denatured by heating at $95^{\circ} \mathrm{C}$ for $2 \mathrm{~min}$. The transcription products were resolved in a 20\% PAGE (19:1 acrylamide:bis-acrylamide) in the presence of $7 \mathrm{M}$ urea and $1 \mathrm{x}$ TBE at constant $50 \mathrm{~W}$ for $50-60 \mathrm{~min}$. Gels were scanned with the 480 $\mathrm{nm}$ (blue) laser, and the RNA bands were detected at $526 \mathrm{~nm}$ emission using Typhoon 9400 Trio scanner (GE Healthcare).

Blue native PAGE analysis [24] of the TECs. The native gel was prepared in a Mini-PROTEAN tetra cell casting module (BioRad) using glass plates separated by $1.5 \mathrm{~mm}$ spacers. The casting module was filled to $80 \%$ capacity with a $13 \%$ polyacrylamide native gel solution $(50 \mathrm{mM}$ Tris- $\mathrm{HCl}$, pH 7.0 at $4{ }^{\circ} \mathrm{C}, 13 \%$ acrylamide:bisacrylamide $32: 1,20 \%$ glycerol, $0.03 \%$ ammonium persulfate and $0.03 \%$ TEMED), and filled with the $4 \%$ polyacrylamide stacking gel solution (50 mM Bis-Tris- $\mathrm{HCl}$, $\mathrm{pH} 7.0$ at $4{ }^{\circ} \mathrm{C}, 4 \%$ acrylamide:bisacrylamide $32: 1,0.06 \%$ ammonium persulfate and $0.06 \%$ TEMED). After polymerization at $25^{\circ} \mathrm{C}$, the gels were stored at $4{ }^{\circ} \mathrm{C}$. The run was performed at $4{ }^{\circ} \mathrm{C}$ in the cold room. During the run set up, the bottom tank was filled with the anode buffer $(50 \mathrm{mM}$ Bis-Tris- $\mathrm{HCl}, \mathrm{pH} 7.0$ at $\left.4^{\circ} \mathrm{C}\right)$, and the gel wells were washed with the cathode buffer A $(50 \mathrm{mM}$ Tricine, $15 \mathrm{mM}$ Bis-Tris- $\mathrm{HCl}, \mathrm{pH} 7.0$ at $4^{\circ} \mathrm{C}$ ). The internal tank was carefully filled with the 
cathode buffer B (0.02\% Coomassie Blue G-250 in the cathode buffer A). The samples were diluted 1:1 with $50 \mathrm{mM}$ Bis-Tris-HCl, pH 7.0 at $4^{\circ} \mathrm{C}, 0.5 \mathrm{mM}$ EDTA, 5\% Coomassie Blue G-250, and loaded to the gel wells. Electrophoresis was performed at $30 \mathrm{~V}$ constant for 30 minutes. The voltage was then increased to $80 \mathrm{~V}$, and kept constant for $3 \mathrm{~h}$ or until the free Coomassie Blue dye reached half of the gel's length. After that the cathode buffer B in the internal tank was changed to the cathode buffer A, and electrophoresis was resumed for 3 more hours, or until the dye reached the bottom of the gel. After visual inspection and white-light digital scanning, the RNA in the gel was detected at $526 \mathrm{~nm}$ emission using Typhoon 9400 Trio scanner (GE Healthcare) as described above.

Electromobility shift assay (EMSA). 200 nM MtbRNAP was incubated with $2 \mu$ M hexahistidinetagged $\mathrm{CarD}$ at $25^{\circ} \mathrm{C}$ for $15 \mathrm{~min}$. A $150 \mathrm{bp}$ DNA fragment containing the M. tuberculosis ribosomal promoter P1Pcl1 [21] was labeled at both 5' ends with FAM by PCR amplification with /56FAM/ATCGAACGGGTATGCTGTTAG and /56FAM/TTGAGTTCTCAAACAACACGCT primers. $20 \mathrm{nM}$ of this construct was added to free MtbRNAP or to the MtbRNAP-CarD complex in TB40, and incubated for $5 \mathrm{~min}$ at $25^{\circ} \mathrm{C} .10,20,30,40$, or $50 \mu \mathrm{g} / \mathrm{ml}$ heparin were added followed by incubation for additional $5 \mathrm{~min}$ at $25^{\circ} \mathrm{C}$. At the end of the incubation, loading buffer $(50 \%$ glycerol, $0.5 \%$ bromophenol blue) was added to the samples, and the DNA-protein complexes were immediately loaded on to a $4 \%$ polyacrylamide gel and resolved at $80 \mathrm{~V}$ for $100 \mathrm{~min}$ in TBE buffer containing $1 \%$ glycerol.

\section{Promoter-dependent initiation on P1Pcl1 promoter.}

$200 \mathrm{nM}$ MtbRNAP and $200 \mathrm{nM}$ DNA template containing the $M$. tuberculosis ribosomal promoter P1Pcl1 in TB were diluted in TB40 and incubated with $2 \mu \mathrm{M}$ CarD or with CarD storage buffer for $5 \mathrm{~min}$ at $37^{\circ} \mathrm{C}$. The reaction volume was $24 \mu$. The resulting complex was split in half and 50 $\mu \mathrm{g} / \mathrm{ml}$ heparin (final concentration) was added to one of the two aliquots for $5 \mathrm{~min}$ at $37^{\circ} \mathrm{C} .100 \mu \mathrm{M}$ each CTP, UTP, and GTP (final concentration) was added to each of the four parallels for $2 \mathrm{~min}$. The resulting TECs were immobilized by a 10 min incubation with $15 \mu 150 \%$ Ni-NTA agarose suspension pre-washed with TB40 (no heparin parallels) or TB40 containing $50 \mu \mathrm{g} / \mathrm{ml}$ heparin at $25^{\circ} \mathrm{C}$. The TECs were washed four times with $1 \mathrm{ml} \mathrm{TB} 40$, and the transcript was labeled by incubation with $0.3 \mu \mathrm{M} \alpha-\left[{ }^{32} \mathrm{P}\right]$ ATP $(3000 \mu \mathrm{Ci} / \mathrm{mmol})$ for $5 \mathrm{~min}$ at $25^{\circ} \mathrm{C}$. The labeled TECs were washed four times with $1 \mathrm{ml} \mathrm{TB} 40$, and chased with $1 \mathrm{mM}$ of all four NTPs for $1 \mathrm{~min}$ at $25^{\circ} \mathrm{C}$. The reaction was stopped by addition of an equal volume of a $2 \mathrm{X}$ gel loading buffer (10 $\mathrm{M}$ urea, $0.025 \%$ bromophenol blue, $0.025 \%$ xylene cyanol, $100 \mathrm{mM}$ EDTA). The samples were resolved in $20 \%$ PAGE (19:1 acrylamide: bisacrylamide) containing $7 \mathrm{M}$ urea and $1 \mathrm{X}$ TBE at $50 \mathrm{~W}$ for $50 \mathrm{~min}$. 
Promoter-dependent initiation on $\lambda$ PR promoter. A DNA fragment containing bacteriophage $\lambda$ $\mathrm{pR}$ and pRM promoters was amplified from plasmid pPIA2-6 [25] with the following primers: 5'-GCGGATACATATTTGAATGT-3' and 5'- ATTTCAACAAAACGCTGGTCCTTTCCGG CAATCAGGCG-3'. The resulting 5507 bp DNA template was used for in vitro transcription assay. Approximately $4 \mathrm{nM}$ of DNA was incubated with $100 \mathrm{nM}$ MtbRNAP at $25^{\circ} \mathrm{C}$ for $15 \mathrm{~min}$.

Subsequently, TB40 with or without $50 \mu \mathrm{g} / \mathrm{ml}$ heparin was added, and the mixture was incubated for 1 min. Transcription elongation was started by addition of $100 \mu \mathrm{M}$ each GTP, ATP, CTP, and UTP spiked with $0.1 \mu \mathrm{Ci} / \mu 1[0.3 \mu \mathrm{M}] \alpha-\left[{ }^{32} \mathrm{P}\right]$ GTP at $25^{\circ} \mathrm{C}$. The reaction was stopped by addition of an equal volume of a $2 \mathrm{X}$ gel loading buffer (10 M urea, $0.025 \%$ bromophenol blue, $0.025 \%$ xylene cyanol, 100 mM EDTA). The samples were run in 4\% PAGE (29:1 acrylamide: bisacrylamide) containing $7 \mathrm{M}$ urea and $1 \mathrm{X}$ TBE starting at $1300 \mathrm{~V}$ and kept at constant power of $18 \mathrm{~W}$.

\section{RESULTS AND DISCUSSION}

$\mathrm{Ni}^{2+}$ affinity chromatography. Recombinant MtbRNAP was separated from the endogenous EcoRNAP by $\mathrm{Ni}^{2+}$ affinity chromatography using the $\mathrm{N}$-terminal decahistidine tag on the Mtb $\alpha$ subunits. A combination of stepwise salt increments and a continuous imidazole gradient eliminated most of $E$. coli lysate proteins through this step (Fig. 1). The protein composition of the chromatography fractions indicated that MtbRNAP was eluted with $200 \mathrm{mM}$ imidazole (Fig.1B, fractions E18-E20), in agreement with the previous report [1]. The amounts of $\beta$ and $\beta$ ' subunits were similar, and their ratio was comparable to the stoichiometric ratio of $\beta$ and $\beta$, in the E. coli holoenzyme run along as a control (In Fig. 1B, compare fraction E19 with the lanes showing EcoRNAP). Increase of $\mathrm{NaCl}$ concentration in the elution buffer containing $200 \mathrm{mM}$ imidazole resulted in the appearance of a new peak containing a large excess of $\alpha$ subunit (Fig. 1A, F3 and Fig. 1B, fraction E23).

Mono Q column. In order to obtain highly pure MtbRNAP holoenzyme, and to discriminate against the subunit assemblies with the stoichiometries distinct from the correct $\alpha_{2} \beta \beta^{\prime} \omega \sigma^{\mathrm{A}}$, we used a procedure similar to one developed by Hager and co-authors [26] for the EcoRNAP holoenzyme purification. The pooled E18-E20 fractions $(10.5 \mathrm{mg})$ were diluted and loaded to the Mono Q column. The proteins were eluted by a $\mathrm{NaCl}$ gradient (Fig. 2A), and the protein content of the eluted fractions was analyzed by SDS PAGE (Fig. 2B). Notably, the material eluted at $[\mathrm{NaCl}]$ below $390 \mathrm{mM}$ (fractions 11-27) contained significant excess of $\beta$ subunit over the $\beta$ ' subunit. Application of the $[\mathrm{NaCl}]$ gradient from 390 to $480 \mathrm{mM}$ eluted two 
distinct peaks (Figure 2A and B, fractions 28-34 and 35-40, respectively). Only the last protein-containing peak showed the correct subunit stoichiometry and contained a detectable amount of $\omega$ subunit (Fig. 2B, peak 3). These fractions (35-40) were pooled, concentrated, and diluted with a $2 \mathrm{X}$ storage buffer as described in Materials and Methods. The protein concentration in the final preparation was $1 \mathrm{mg} / \mathrm{ml}(\sim 2 \mu \mathrm{M})$, and the total MtbRNAP yield was $2.5 \mathrm{mg}$. The presence of the subunit sub-assemblies and their separation from the holoenzyme on the MonoQ column was reproducible in different purification runs.

Identification of fractions containing the active MtbRNAP. A convenient promoterindependent activity test was adapted from [22] to evaluate RNAP activity in the representative fractions eluted from Mono Q column. The material loaded on the column, along with the fractions from 18, 27, and 37, were used for the TEC assembly. The fractions assayed for RNAP activity from peaks 1 and 2 were chosen from the left shoulder of each peak to ensure that they do not contain any material from the subsequent peaks. Fraction 37 from peak 3 was chosen for the activity analysis because it contained an apparently stoichiometric amount of $\omega$ subunit (Fig. 2B). The assembled TECs were chased with all four NTPs, and the extension of the RNA, as well as the accumulation of the runoff product were used as indicators of the presence of the catalytically active RNAP. Fig. 2C illustrates that only the imidazole eluate and a representative fraction from peak 3 contained any detectable RNA polymerase activity. We conclude that the other peaks resolved by the anion exchange column correspond to inactive sub-assemblies of the recombinant MtbRNAP subunits. This conclusion is consistent with the wrong stoichiometry of $\alpha, \beta$ and $\beta$ ' subunits and the absence of $\omega$ subunit observed in peaks 1 and 2 .

MtbRNAP activity quantification. To obtain a quantitative estimate of the purified MtbRNAP activity, we looked for the conditions, at which the amount of the assembled TEC is proportional to the amount of MtbRNAP added. The plot in Figure 2D shows that while the amount of the TEC was almost precisely proportional to the amount of RNAP added when the assembly was performed with $200 \mathrm{nM}$ RNA-DNA hybrid, the amount of the resulting TEC plateaued when $100 \mathrm{nM}$ and 50 $\mathrm{nM}$ concentrations of the hybrid were used. It appears that the RNA-DNA hybrid should be added in at least 10-fold molar excess for the accurate MtbRNAP activity measurement. A similar result was obtained for EcoRNAP (Supplemental Fig. 1). Averaging of the six data points obtained with a 10 -fold or higher molar excess of the RNA-DNA hybrid, nearly all (95\% with a $6 \%$ standard error) 
purified MtbRNAP molecules formed an active TEC (Fig. 2D). We conclude that the removal of the inactive sub-assemblies by chromatography on MonoQ column is essential for obtaining highly active and homogeneous holoenzyme. Next, we subjected this preparation of MtbRNAP to additional functional tests.

Stability of the TECs. EcoRNAP requires the $9 \mathrm{bp}$ RNA-DNA hybrid and at least $10 \mathrm{bp}$ dsDNA downstream its active site to form stable TECs [20]. To test if the downstream dsDNA is required for MtbRNAP TEC, the TECs were assembled on a short template with only $13 \mathrm{nt}$ downstream from the RNA 3' end to rule out formation of a hairpin by the downstream ssDNA (Fig. 3A and Table 2, TDS45 and RNA7FL extended to RNA A9 by incorporation of GMP and AMP). The TEC formed in the absence of the non-template NDS45 DNA strand dissociated after exposure to $1 \mathrm{M} \mathrm{KCl} \mathrm{(Fig.} \mathrm{3A,} \mathrm{compare} \mathrm{lane} 2$ and lanes 3-5), while about $1 / 2$ of the dsTEC retained catalytic activity even after $30 \mathrm{~min}$ incubation with $1 \mathrm{M} \mathrm{KCl}$ (lane 10). Therefore, the requirement for the downstream dsDNA is conserved between MtbRNAP and EcoRNAP.

To establish whether MtbRNAP TECs retain their integrity upon prolonged storage in TB40, we assembled the TECs using the RNA-DNA scaffold designed for the single-molecule analyses of transcription elongation [23]. The assembly was performed with just an RNADNA hybrid (ssTEC) or with the RNA-DNA hybrid followed by the addition of the nontemplate DNA strand (dsTEC) (Fig. 3B). The TECs were analyzed by native blue PAGE [24]. The protein component and the RNA component were detected in the same gel by Coomassie staining and by fluorescence, respectively, (Fig. 3B, protein and RNA in the TEC panels). The electrophoretic mobility of the TECs is distinct from the mobility of the free MtbRNAP holoenzyme. Note that the latter migrates as two distinct bands. The TECs have an intermediate mobility, suggesting that the slower band in the free MtbRNAP holoenzyme corresponds to a dimer, which dissociates upon formation of the TEC. Fig. 3B demonstrates that the TECs formed both in the absence and in the presence of the non-template DNA strand retain their ability to elongate the RNA primer even after $6 \mathrm{~h}$ incubation, suggesting that in the low salt conditions stability of the MtbRNAP TEC on this scaffold is not compromised by omission of the non-template DNA. The incorporation of the non-template DNA strand is efficient, as evidenced by the mobility shift that the majority of the TEC undergoes in the presence of the non-template DNA strand. In this scaffold, 9 nt from the 3' end of RNA primer is complementary to the template DNA strand. The RNA in the TEC can be extended to 2-nt by enzymatic incorporation of GMP and CMP. In agreement with the non-denaturing gel 
results, the identical fraction of RNA extended before or after the $6 \mathrm{~h}$ incubation of the ssTEC and dsTEC indicates that both variants of the TEC are resistant to dissociation.

Transcription of the single-strand and the double-strand DNA templates and sequencespecific pausing pattern. Direct comparison of the transcript elongation patterns within the same sequence context on the single-strand (ss) and the double-strand (ds) DNA, reveal only the minor differences between MtbRNAP and EcoRNAP (Fig. 4). On the dsDNA template, both RNAPs undergo strong sequence-specific pausing at the same position U12, within the sequence context $\mathrm{C}_{-10} \mathrm{AUGAACUGUA}$, which differs from the previously reported consensus pause sequence for EcoRNAP [27-29] only by the CMP, not GMP, encoded 10 nt upstream from the pause site. MtbRNAP is more prone to transcription arrest $5 \mathrm{bp}$ from the end of the dsDNA template, at U31 (compare lanes 10-12 and 22-24 in Fig. 4).

It was unexpected to observe that EcoRNAP transcribes to the end of the ss template and adds a few more NMPs beyond the end of the template (Fig. 4, lanes 16-18), which is in disagreement with the previously reported low processivity of EcoRNAP in the absence of the nontemplate DNA strand [30]. It is likely that the non-complementary RNA tail present in the nucleic acid scaffolds used in this work promotes transcript displacement from the RNA-DNA hybrid thus preventing the proposed clash between the EcoRNAP lid domain and the transcript 5' end [30]. In contrast, MtbRNAP has a lower processivity on the ssDNA than EcoRNAP, and fails to reach the end of the template. MtbRNAP undergoes transcription arrest or dissociation at positions U18 and U23 (Fig. 4, lanes 4-6).

Elongation stalling and escape from the stall. The setup of transcription elongation assays previously developed and optimized for the single-molecule experiments with $S$. cerevisiae RNAP II [23] requires the assembly of the TEC on the RNA9FL9-TDS93-NDS96 scaffold, and walking of the RNAP away from the assembly site by addition of ATP, CTP, and GTP. Such complex is captured in optical tweezers, and the elongation is resumed by adding all four NTPs. The success of this experimental strategy depends, among other factors, on the efficiency of RNAP escape from the stalled state induced by nucleotide starvation. Figure 5 demonstrates that MtbRNAP assembled on the RNA9FL9-TDS93-NDS96 scaffold efficiently extends the RNA in a template-specific manner. Upon incubation with GTP and CTP, the RNA primer is elongated $2 \mathrm{nt}$, and MtbRNAP stops because the next cognate ATP is lacking. Upon incubation with ATP, GTP, and CTP, MtbRNAP adds 29 nt to the transcript and is stalled because the next cognate UTP is missing. Importantly, the stalled TECs efficiently 
resume elongation when $1 \mathrm{mM}$ each of all four NTPs are added to the reaction mix. Apparently, MtbRNAP does not undergo transcription arrest at the stall sites tested and does not depend on any external factors to resume transcript elongation from them.

\section{Transcription factor-dependent formation of the initiation complex by MtbRNAP}

holoenzyme. Formation of the initiation complexes at $M$. tuberculosis ribosomal promoters P1Pcl1 [21] was analyzed by EMSA. The 5 min pre-incubation of promoter DNA with MtbRNAP at $25^{\circ} \mathrm{C}$ was sufficient for an efficient formation of the RNAP-DNA complex, which is in agreement with the previously reported 24 min half-life of the open complex [31,32]. In the absence of heparin, all the input promoter DNA interacts with MtbRNAP, forming the complexes with very slow mobility (Fig. 6A, lane 1). Later, in order to observe formation of the transcription-competent open promoter complexes, different concentrations of heparin, a negative polyelectrolite able to bind free DNA and actively dissociate non-specific RNAP-DNA complexes and closed promoter complexes [33] were added. Even very low amounts of heparin disrupt the interaction of MtbRNAP with the DNA (Fig. 6A, lanes 2-6), suggesting that the DNA shift is caused by weak non-specific binding of MtbRNAP to the DNA, rather than by formation of the stable initiation complex.

To increase the specificity and stability of MtbRNAP interaction with the promoter, we purified Mtb transcription factor CarD [34] (Supplemental Fig. 2A and B). The 2 L culture yielded approximately $8 \mathrm{mg}$ of hexahistidine-tagged CarD, which was further purified by a size exclusion column. CarD elution pattern suggested that it forms a dimer (Supplemental Fig. 2C and D). Dimerization of MtbCarD is consistent with the previously reported dimerization of CarD from other mycobacteria $[35,36]$. When MtbRNAP is pre-incubated with the purified CarD, a heparinresistant promoter open complex is formed (Fig. 6A, lanes lanes 8 -12). MtbRNAP was preincubated with CarD before the addition of the promoter-containing DNA fragment, because, apparently, this factor interacts exclusively with MtbRNAP holoenzyme, and not with the DNA [31]. The band corresponding to the heparin-resistant open promoter complexes migrates faster than the non-specific heparin-sensitive MtbRNAP-DNA complexes (compare lane 7 in Fig. 6A with lanes 8 - 12).

Next, the CarD effect on transcription initiation was tested in a promoter-specific transcription assay on the same template. The initiation complexes were formed on the same DNA template that was used for the EMSA with or without CarD, challenged with heparin, and then purified CTP, GTP, and UTP were added to promote formation of the TEC with the 9-nt transcript 5'-GUUGCCCCG-3' stalled because the next cognate ATP was lacking. The TEC was immobilized on Ni-NTA agarose beads, the NTPs were removed by washing the beads with TB40, and the RNA was labeled by incubation with $\alpha-\left[{ }^{32} \mathrm{P}\right]$ ATP producing the expected $11 \mathrm{nt}$ RNA product (Fig. 6B, 
lanes 1, 5, and 7). Upon addition of all four NTPs the RNA was extended to the runoff product of the expected length (lanes 2, 6, and 8). Consistently with EMSA results, heparin inhibited transcription initiation in the absence of CarD (lanes 3 and 4).

Despite the predominance of the non-specific RNAP-DNA interactions detected by EMSA in the absence of heparin, MtbRNAP holoenzyme initiated at $\lambda \mathrm{pR}$ promoter with an efficiency similar to EcoRNAP holoenzyme (Fig. 6C, lanes 1 and 2). Heparin did not affect promoterdependent transcription by EcoRNAP, but completely inhibited MtbRNAP (lanes 3 and 4). A longer exposure of the gels revealed that in the presence of heparin a less prominent, 255-nt transcript is synthesized by MtbRNAP holoenzyme in the presence of heparin (Fig. 6C, lanes 2 and 5). We interpreted this product as a transcript initiated from $\lambda \mathrm{pRM}$ promoter, which is also present in the template DNA, or as a product of premature arrest of elongation from $\lambda \mathrm{pR}$. Notably, CarD promotes MtbRNAP-dependent transcription from $\lambda$ pRM in the presence of heparin (Fig. $6 \mathrm{D}$, lanes 3 and 6), probably, by reducing the rate of transcriptional bubble collapse [34]. The latter result indicates that the stabilizing effect of CarD on the open promoter complex is not specific exclusively to Mtb promoters.

\section{CONCLUSIONS}

A detailed protocol for the expression and purification of MtbRNAP holoenzyme is presented at a small scale ( $\sim \mathrm{g}$ of bacterial pellet), based on a strategy of co-expression from two plasmids similar to the one previously described by [1]. The plasmid pACYC Duet-AZD was designed to contain simultaneously the $\alpha, \omega$ and $\sigma^{\mathrm{A}}$ subunits, thus allowing for the assembly of MtbRNAP holoenzyme. The purified holoenzyme formed stable, heparin-resistant pre-initiation complexes only in the presence of CarD. This transcription initiation factor was also necessary to produce promoterdependent initiation above the detection limits. In contrast, stable ternary elongation complexes can be assembled from MtbRNAP and synthetic RNA and DNA oligonucleotides without the aid of CarD. These ternary (DNA, RNA and protein) complexes can be used in a convenient activity assay that eliminates the need of radioactively labeled nucleotides.

\section{ACKNOWLEDGEMENTS}

This work was supported in part by a special grant contract and a travel award from CONCYTEC, Perú [FONDECYT N 196-2013 and $\mathrm{N}^{\circ}$ 033-2015-FONDECYT-DEC], by the National Institutes of Health [grant \#R01GM032543], the U.S. Department of Energy Office of Basic Energy Sciences Nanomachine Program [contract \#DE-AC02-05CH11231], and by the Intramural Research Program of the National Institutes of Health, NCI, Center for Cancer Research. 


\section{AUTHOR CONTRIBUTIONS}

O.H.-A., D.G.G., C.J.B., M.K., L.L., and M.L.K. designed the protein expression and purification setups and the experiments, O. H.-A. and L.L. performed protein purification, O. H.-A. and M.L.K. performed the experiments, O. H.-A., D.G.G., C.J.B. and M.L.K. wrote the manuscript helped by the input from L.L and M.K.

\section{REFERENCES}

[1] R. Banerjee, P. Rudra, R.K. Prajapati, S. Sengupta, J. Mukhopadhyay, Optimization of recombinant Mycobacterium tuberculosis RNA polymerase expression and purification, Tuberc. Edinb. Scotl. 94 (2014) 397-404. doi:10.1016/j.tube.2014.03.008.

[2] A. Czyz, R.A. Mooney, A. Iaconi, R. Landick, Mycobacterial RNA polymerase requires a Utract at intrinsic terminators and is aided by NusG at suboptimal terminators, mBio. 5 (2014) e00931. doi:10.1128/mBio.00931-14.

[3] S.K. Gill, G.A. Garcia, Rifamycin inhibition of WT and Rif-resistant Mycobacterium tuberculosis and Escherichia coli RNA polymerases in vitro, Tuberc. Edinb. Scotl. 91 (2011) 361-369. doi:10.1016/j.tube.2011.05.002.

[4] K.S. Murakami, X-ray crystal structure of Escherichia coli RNA polymerase $\sigma 70$ holoenzyme, J. Biol. Chem. 288 (2013) 9126-9134. doi:10.1074/jbc.M112.430900.

[5] M.X. Ho, B.P. Hudson, K. Das, E. Arnold, R.H. Ebright, Structures of RNA polymeraseantibiotic complexes, Curr. Opin. Struct. Biol. 19 (2009) 715-723. doi:10.1016/j.sbi.2009.10.010.

[6] R. Mariani, S.I. Maffioli, Bacterial RNA polymerase inhibitors: an organized overview of their structure, derivatives, biological activity and current clinical development status, Curr. Med. Chem. 16 (2009) 430-454.

[7] W.R. McClure, C.L. Cech, On the mechanism of rifampicin inhibition of RNA synthesis, J. Biol. Chem. 253 (1978) 8949-8956.

[8] M. Aquinas, Short-course therapy for tuberculosis, Drugs. 24 (1982) 118-132.

[9] J. Ena, V. Valls, Short-course therapy with rifampin plus isoniazid, compared with standard therapy with isoniazid, for latent tuberculosis infection: a meta-analysis, Clin. Infect. Dis. Off. Publ. Infect. Dis. Soc. Am. 40 (2005) 670-676. doi:10.1086/427802.

[10] B.P. Goldstein, Resistance to rifampicin: a review, J. Antibiot. (Tokyo). 67 (2014) 625-630. doi:10.1038/ja.2014.107.

[11] V. Svetlov, I. Artsimovitch, Purification of bacterial RNA polymerase: tools and protocols, Methods Mol. Biol. Clifton NJ. 1276 (2015) 13-29. doi:10.1007/978-1-4939-2392-2_2.

[12] S.G. Kansara, M.V. Sukhodolets, Oligomerization of the E. coli core RNA polymerase: formation of $\left(\alpha 2 \beta \beta^{\prime} \omega\right) 2$-DNA complexes and regulation of the oligomerization by auxiliary subunits, PloS One. 6 (2011) e18990. doi:10.1371/journal.pone.0018990.

[13] M. Imashimizu, M. Kashlev, Unveiling translocation intermediates of RNA polymerase, Proc. Natl. Acad. Sci. U. S. A. 111 (2014) 7507-7508. doi:10.1073/pnas.1406413111.

[14] E.F. Ruff, A.C. Drennan, M.W. Capp, M.A. Poulos, I. Artsimovitch, M.T. Record, E. coli RNA Polymerase Determinants of Open Complex Lifetime and Structure, J. Mol. Biol. 427 (2015) 2435-2450. doi:10.1016/j.jmb.2015.05.024.

[15] I. Artsimovitch, V. Svetlov, L. Anthony, R.R. Burgess, R. Landick, RNA polymerases from Bacillus subtilis and Escherichia coli differ in recognition of regulatory signals in vitro, J. Bacteriol. 182 (2000) 6027-6035. 
[16] R.M. Harshey, T. Ramakrishnan, Purification and properties of DNA-dependent RNA polymerase from Mycobacterium tuberculosis H37RV, Biochim. Biophys. Acta. 432 (1976) 49-59.

[17] A. China, V. Nagaraja, Purification of RNA polymerase from mycobacteria for optimized promoter-polymerase interactions, Protein Expr. Purif. 69 (2010) 235-242. doi:10.1016/j.pep.2009.09.022.

[18] J.-F. Jacques, S. Rodrigue, R. Brzezinski, L. Gaudreau, A recombinant Mycobacterium tuberculosis in vitro transcription system, FEMS Microbiol. Lett. 255 (2006) 140-147. doi:10.1111/j.1574-6968.2005.00071.x.

[19] Y. Hu, Z. Morichaud, A.S. Perumal, F. Roquet-Baneres, K. Brodolin, Mycobacterium RbpA cooperates with the stress-response $\sigma \mathrm{B}$ subunit of RNA polymerase in promoter DNA unwinding, Nucleic Acids Res. 42 (2014) 10399-10408. doi:10.1093/nar/gku742.

[20] I. Sidorenkov, N. Komissarova, M. Kashlev, Crucial role of the RNA:DNA hybrid in the processivity of transcription, Mol. Cell. 2 (1998) 55-64.

[21] Y. Hu, Z. Morichaud, S. Chen, J.-P. Leonetti, K. Brodolin, Mycobacterium tuberculosis RbpA protein is a new type of transcriptional activator that stabilizes the $\sigma$ A-containing RNA polymerase holoenzyme, Nucleic Acids Res. 40 (2012) 6547-6557. doi:10.1093/nar/gks346.

[22] M.L. Kireeva, C. Domecq, B. Coulombe, Z.F. Burton, M. Kashlev, Interaction of RNA polymerase II fork loop 2 with downstream non-template DNA regulates transcription elongation, J. Biol. Chem. 286 (2011) 30898-30910. doi:10.1074/jbc.M111.260844.

[23] C. Hodges, L. Bintu, L. Lubkowska, M. Kashlev, C. Bustamante, Nucleosomal fluctuations govern the transcription dynamics of RNA polymerase II, Science. 325 (2009) 626-628. doi:10.1126/science.1172926.

[24] G.J. Fiala, W.W.A. Schamel, B. Blumenthal, Blue native polyacrylamide gel electrophoresis (BN-PAGE) for analysis of multiprotein complexes from cellular lysates, J. Vis. Exp. JoVE. (2011). doi:10.3791/2164.

[25] R.J. Davenport, G.J. Wuite, R. Landick, C. Bustamante, Single-molecule study of transcriptional pausing and arrest by E. coli RNA polymerase, Science. 287 (2000) 24972500.

[26] D.A. Hager, D.J. Jin, R.R. Burgess, Use of Mono Q high-resolution ion-exchange chromatography to obtain highly pure and active Escherichia coli RNA polymerase, Biochemistry (Mosc.). 29 (1990) 7890-7894.

[27] M. Imashimizu, H. Takahashi, T. Oshima, C. McIntosh, M. Bubunenko, D.L. Court, M. Kashlev, Visualizing translocation dynamics and nascent transcript errors in paused RNA polymerases in vivo, Genome Biol. 16 (2015) 98. doi:10.1186/s13059-015-0666-5.

[28] M.H. Larson, R.A. Mooney, J.M. Peters, T. Windgassen, D. Nayak, C.A. Gross, S.M. Block, W.J. Greenleaf, R. Landick, J.S. Weissman, A pause sequence enriched at translation start sites drives transcription dynamics in vivo, Science. 344 (2014) 1042-1047. doi:10.1126/science.1251871.

[29] I.O. Vvedenskaya, H. Vahedian-Movahed, J.G. Bird, J.G. Knoblauch, S.R. Goldman, Y. Zhang, R.H. Ebright, B.E. Nickels, Interactions between RNA polymerase and the "core recognition element" counteract pausing, Science. 344 (2014) 1285-1289. doi:10.1126/science.1253458.

[30] T. Naryshkina, K. Kuznedelov, K. Severinov, The role of the largest RNA polymerase subunit lid element in preventing the formation of extended RNA-DNA hybrid, J. Mol. Biol. 361 (2006) 634-643. doi:10.1016/j.jmb.2006.05.034.

[31] J. Rammohan, A. Ruiz Manzano, A.L. Garner, C.L. Stallings, E.A. Galburt, CarD stabilizes mycobacterial open complexes via a two-tiered kinetic mechanism, Nucleic Acids Res. 43 (2015) 3272-3285. doi:10.1093/nar/gkv078.

[32] P. Schickor, W. Metzger, W. Werel, H. Lederer, H. Heumann, Topography of intermediates in transcription initiation of E. coli, EMBO J. 9 (1990) 2215-2220. 
[33] C.J. Dayton, D.E. Prosen, K.L. Parker, C.L. Cech, Kinetic measurements of Escherichia coli RNA polymerase association with bacteriophage T7 early promoters, J. Biol. Chem. 259 (1984) 1616-1621.

[34] E. Davis, J. Chen, K. Leon, S.A. Darst, E.A. Campbell, Mycobacterial RNA polymerase forms unstable open promoter complexes that are stabilized by CarD, Nucleic Acids Res. 43 (2015) 433-445. doi:10.1093/nar/gku1231.

[35] S.P. Gangwar, S.R. Meena, A.K. Saxena, Structure of the carboxy-terminal domain of Mycobacterium tuberculosis CarD protein: an essential rRNA transcriptional regulator, Acta Crystallogr. Sect. F Struct. Biol. Commun. 70 (2014) 160-165. doi:10.1107/S2053230X13034407.

[36] G. Kaur, D. Dutta, K.G. Thakur, Crystal structure of Mycobacterium tuberculosis CarD, an essential RNA polymerase binding protein, reveals a quasidomain-swapped dimeric structural architecture, Proteins. 82 (2014) 879-884. doi:10.1002/prot.24419.

[37] M.L. Kireeva, M. Kashlev, Mechanism of sequence-specific pausing of bacterial RNA polymerase, Proc. Natl. Acad. Sci. U. S. A. 106 (2009) 8900-8905. doi:10.1073/pnas.0900407106. 


\section{FIGURE CAPTIONS}

Figure 1. Co-expression of MtbRNAP Subunits in $E$. coli and $\mathrm{Ni}^{2+}$ affinity chromatography. (A) Elution profile of the E. coli whole cell lysate containing recombinant MtbRNAP subunits from $\mathrm{Ni}^{2+}$ affinity column with imidazole gradient and a stepwise increase in $[\mathrm{NaCl}]$. The fraction numbers are shown on top of the horizontal axis in red. (B) SDS-PAGE analysis of the eluted fractions.

Figure 2. MonoQ Purification of the MtbRNAP. (A) Elution profile of $\mathrm{Ni}^{2+}$-affinity purified MtbRNAP from MonoQ column with a $\mathrm{NaCl}$ gradient. The odd fraction numbers are indicated on top of the horizontal axis. (B) SDS-PAGE analysis of the fractions eluted from MonoQ column. $L$ (for Loading) is the material eluted from the $\mathrm{Ni}^{2+}$ affinity column (F2); FT and Wash are the fractions collected before application of the salt gradient; Peak1, Peak2, and Peak3 corresponding to the peaks in the $\mathrm{A}_{280}$ profile in (A); E. coli RNAP holoenzyme was used as reference. (C) Evaluation of the transcriptional activity of the fractions from MonoQ column. 12 pmol of RNA7FL-TDS76 hybrid (Table 2) in $8 \mu \mathrm{l} \mathrm{TB} 40$ containing $20 \mu \mathrm{M}$ each ATP and GTP were used for the TEC assembly with $3 \mu 1$ of the F2 fraction of the imidazole eluate (L) or fractions 17,27 , and 37 from MonoQ; 15 pmol NDS79 were added to each reaction. The TEC was chased with 1 mM NTPs for up to 40s. (D) Quantification of MtbRNAP activity. The TECs were assembled with 0.5, 1, or 2 pmol of RNA9Cre-TDS57 hybrid, 0.4, 0.2, 0.1, and 0.05 pmol MtbRNAP, and a 2-fold molar excess of NDS57 in $10 \mu \mathrm{lTB}$. The fraction of the active TEC was quantified as the \% of the RNA extended after 5 min incubation with $10 \mu \mathrm{M}$ each GTP + UTP and the [TEC] was quantified based on the total [RNA] and plotted $v s$ [RNAP]. Each series represents the results obtained with a certain concentration of the RNA-DNA hybrid. The inset shows a gel for the " $100 \mathrm{nM}$ " (1 pmol of RNA9Cre-TDS57 hybrid) series.

Figure 3. Stability of MtbRNAP TECs. (A) Stability of MtbRNAP TECs in high salt. The TEC was assembled with 20 pmol MtbRNAP and 45 pmol of RNA7FL-TDS45 hybrid in $40 \mu 1$ TB40 containing $10 \mu \mathrm{M}$ each ATP and GTP. 45 pmol NDS45 was added to one half of this ssTEC to form the dsTEC. The TECs were mixed with $1 / 2$ volume of $3 \mathrm{M} \mathrm{KCl}$, and $1 \mu \mathrm{l}$ aliquots were removed after 3,10 , and 30 min of incubation (lanes $3-5$ and $8-10$ ), mixed with $4 \mu 1$ of TB40 containing $100 \mu \mathrm{M}$ CTP, and elongation was stopped by addition of $10 \mu \mathrm{l}$ of gel loading buffer after $10 \mathrm{~s}$ incubation. The control TECs were mixed with $1 / 2$ volume of water, and $1 \mu$ laliquots were mixed with TB40 with (lanes 2 and 7) or without CTP (lanes 1 and 6), and the gel loading buffer was added after $10 \mathrm{~s}$. The $\%$ of dissociated TEC was quantified as fraction of A9 RNA that was not extended after incubation with CTP. (B) Stability of the TECs on the template designed for the 
single-molecule assays. The TECs were assembled with 6 pmol RNA9-FL9 - TDS93 hybrid and 4 pmol MtbRNAP in $60 \mu \mathrm{l}$ TB40 to form the ssTEC. 15 pmol NDS96 was added to one half of the ssTEC to form the dsTEC. Each TEC was divided in 4 aliquots, and $20 \mu \mathrm{M}$ each GTP and CTP were added before or after $6 \mathrm{~h}$ incubation on ice. Coomasie Blue dye was added to the MtbRNAP, EcoRNAP, RNA-DNA hybrid and to one half of the TEC aliquots, and the material was analyzed by PAGE in non-denaturing (native) conditions. The Coomassie-stained proteins are shown in the Protein panel. The RNA in the same gel is shown in the middle (RNA in the TEC) panel. 2-nt RNA extension by ssTEC and dsTEC was analyzed in the remaining TEC by PAGE in denaturing conditions. The positions of the ssTEC, dsTEC in the native gel, and of the RNA primer RNA9-FL9 and elongated product G11 in the denaturing PAGE are indicated with arrows.

Figure 4. Transcription pattern on SSDNA and dsDNA templates. The TECs were formed as in Fig. 2D with 0.2 pmol MtbRNAP or EcoRNAP and 2 pmol of RNA9Cre-TDS57 hybrid. 2 pmol of NDS57 was added to one half of each TEC. The TECs were purified from the excess of RNA and DNA on centrifugal concentrators with $100 \mathrm{kDa}$ cutoff, and chased with $10 \mu \mathrm{M}$ NTP at $37^{\circ} \mathrm{C}$. The positions of the RNA primer, main pause and arrest sites on the dsDNA template, and the runoff transcript are indicated at left.

\section{Figure 5. MtbRNAP escape from the stall on the template designed for the single molecule} applications. MtbRNAP TEC was formed by incubation of 6 pmol RNA9-FLTDS93 hybrid with 4 pmol MtbRNAP and 15 pmol NDS96 in $55 \mu \mathrm{l}$ TB. The TEC was walked $2 \mathrm{nt}$ or $29 \mathrm{nt}$ downstream by incubation with $20 \mu \mathrm{M}$ each GTP and CTP to obtain the stalled TEC G11 or with $20 \mu \mathrm{M}$ each ATP, GTP and CTP to obtain the stalled TEC C38. Elongation was resumed by addition of a $1 \mathrm{mM}$ NTPs for the indicated times. The positions of the RNA primer, stall sites, and the runoff transcript template are indicated at left.

\section{Figure 6. Stabilization of MtbRNAP promoter binding by transcription initiation factor}

CarD. (A) Initiation complex formation on the Mtb ribosomal promoter. The MtbRNAP alone or MtbRNAP pre-incubated with CarD was added to the DNA fragment bearing Mtb ribosomal promoters P1Pcl1. The DNA-protein complexes were challenged by heparin. The positions of the bands corresponding to the free DNA, heparin-sensitive (non-specific) and heparin-resistant (open promoter) complexes are indicated at left. (B) Transcription initiation on P1Pcl1 promoter and elongation. MtbRNAP with or without CarD was pre-incubated with the same template as in (A), and challenged with $50 \mu \mathrm{g} / \mathrm{ml}$ heparin. Transcription was initiated by addition of CTP, GTP, and UTP, and the resulting TECs were immobilized on Ni-NTA, purified, labeled with $\alpha-\left[{ }^{32} \mathrm{P}\right]$ ATP and chased with $1 \mathrm{mM}$ of all four NTPs for $1 \mathrm{~min}$. (C) Transcription initiation on a template containing 
$\lambda$ pR promoter. MtbRNAP (lanes 1and 3, Mtb) and EcoRNAP holoenzymes (lanes 2 and 4, Eco) were incubated with an $863 \mathrm{bp}$ DNA fragment containing the $\lambda \mathrm{pR}$ and $\mathrm{pRM}$ promoters. The complexes were incubated with buffer or challenged with $50 \mu \mathrm{g} / \mathrm{ml}$ heparin before chase in the presence of $\alpha-[2 \mathrm{P}]$ GTP. The product corresponding to a runoff transcript initiated at $\lambda \mathrm{pR}$ promoter is indicated. (D) CarD effect on transcription by MtbRNAP. The experiment was performed as in (C) with MtbRNAP, which was used alone or pre-incubated with a 20-fold molar excess of CarD. The two main transcription products are indicated at left, and the sizes of the reference bands are shown at right. 


\begin{tabular}{|c|c|}
\hline Buffer & Composition \\
\hline Lysis buffer & $\begin{array}{l}150 \mathrm{mM} \text { Tris-acetate } \mathrm{pH} 7.9 \text { at } 25^{\circ} \mathrm{C}, 50 \mathrm{mM} \text { potassium acetate, } 5 \mathrm{mM} \\
\mathrm{MgCl}_{2}, 0.5 \mathrm{mM} \text { EDTA, } 10 \mu \mathrm{M} \mathrm{ZnSO}_{4}, 2 \mathrm{mM} \beta \text {-mercaptoethanol, } 0.3 \mathrm{~g} / \mathrm{ml} \\
\text { lysozyme, } 1 \mathrm{X} \text { protease inhibitors }\end{array}$ \\
\hline $\begin{array}{l}\text { 100X protease } \\
\text { inhibitors }\end{array}$ & $\begin{array}{l}8.5 \mathrm{mg} / \mathrm{ml} \text { PMSF, } 33 \mathrm{mg} / \mathrm{ml} \text { benzamidine, } 0.03 \mathrm{mg} / \mathrm{ml} \text { leupeptin, } 0.14 \mathrm{mg} / \mathrm{ml} \\
\text { pepstatin, } 0.2 \mathrm{mg} / \mathrm{ml} \text { chymostatin in ethanol }\end{array}$ \\
\hline A-200 & $\begin{array}{l}20 \mathrm{mM} \text { Tris- } \mathrm{HCl} \mathrm{pH} 7.9 \text { at } 25^{\circ} \mathrm{C}, 10 \mathrm{mM} \mathrm{MgCl} \\
2,200 \mathrm{mM} \mathrm{KCl}, 1.4 \mathrm{mM} \\
\beta \mathrm{ME}, 0.1 \mathrm{mM} \text { PMSF }\end{array}$ \\
\hline A-1000 & $\begin{array}{l}20 \mathrm{mM} \text { Tris- } \mathrm{HCl} \mathrm{pH} 7.9 \text { at } 25^{\circ} \mathrm{C}, 10 \mathrm{mM} \mathrm{MgCl} 2,1000 \mathrm{mM} \mathrm{KCl}, 1.4 \mathrm{mM} \\
\beta \mathrm{ME}, 0.1 \mathrm{mM} \text { PMSF }\end{array}$ \\
\hline TGEB & $\begin{array}{l}40 \mathrm{mM} \text { Tris- } \mathrm{HCl} \mathrm{pH} 8.0 \text { at } 25^{\circ} \mathrm{C}, 0.5 \mathrm{mM} \text { EDTA, } 5 \% \text { glycerol, } 0.1 \mathrm{mM} \\
\text { PMSF, } 1.4 \mathrm{mM} \beta \mathrm{ME}\end{array}$ \\
\hline Storage buffer & $\begin{array}{l}40 \mathrm{mM} \text { Tris- } \mathrm{HCl} \mathrm{pH} 8.0 \text { at } 25^{\circ} \mathrm{C}, 360 \mathrm{mM} \mathrm{KCl}, 20 \mu \mathrm{M} \mathrm{ZnSO}_{4}, 2 \mathrm{X} \text { protease } \\
\text { inhibitors, } 2 \mathrm{mM} \text { DTT }\end{array}$ \\
\hline $\begin{array}{l}\text { Transcription } \\
\text { buffer (TB40) }\end{array}$ & $20 \mathrm{mM}$ Tris- $\mathrm{HCl} \mathrm{pH} 7.9$ at $25^{\circ} \mathrm{C}, 40 \mathrm{mM} \mathrm{KCl}, 5 \mathrm{mM} \mathrm{MgCl}{ }_{2}$ \\
\hline $\begin{array}{l}\text { Chase buffer } \\
10 \mathrm{x}\end{array}$ & $\begin{array}{l}1 \mathrm{mM} \mathrm{GTP}, 1 \mathrm{mM} \text { ATP, } 1 \mathrm{mM} \mathrm{CTP}, 1 \mathrm{mM} \mathrm{UTP}, 0.1 \mu \mathrm{Ci} / \mu \mathrm{l}[0.3 \mu \mathrm{M}] \alpha-[\mathrm{P}]^{32} \\
\text { GTP }\end{array}$ \\
\hline $\begin{array}{l}\text { Gel loading } \\
\text { buffer }\end{array}$ & $\begin{array}{l}10 \mathrm{M} \text { urea, } 0.025 \% \text { bromophenol blue, } 0.025 \% \text { xylene cyanol, } 100 \mathrm{mM} \\
\text { EDTA }\end{array}$ \\
\hline
\end{tabular}

Table 1. Buffer solutions for protein purification and functional assays 


\begin{tabular}{|c|c|}
\hline Name & Sequence, $5^{\prime}$ to 3 ' \\
\hline RNA9-FL9* & /56FAM/UUACUUCGACGCCCGA \\
\hline RNA7FL** & /56FAM/UUCAUUCCCGAGAGG \\
\hline RNA9Cre & /56FAM/ CCCCCCCCGUCAUGAAC \\
\hline TDS57 & $\begin{array}{l}\text { TGTTTCACTATCCAGGTTACGGATACAGTTCATGACAATATTTACATTGG } \\
\text { TCCAGCC }\end{array}$ \\
\hline NDS57 & $\begin{array}{l}\text { GGCTGGACCAATGTAAATATTGTCATGAACTGTATCCGTAACCTGGATAG } \\
\text { TGAAAC }\end{array}$ \\
\hline NDS79** & $\begin{array}{l}\text { CCTATAGGATACTTAAGCCATCGAGAGGGACACGGCGAATAGCCATCCC } \\
\text { AATCCACACGTCCAACGGGGCAAACCGTA }\end{array}$ \\
\hline TDS76** & $\begin{array}{l}\text { GGTTTGCCCCGTTGGACGTGTGGATTGGGATGGCTATTCGCCGTGTCCCT } \\
\text { CTCGATGGCTGTAAGTATCCTATAGG }\end{array}$ \\
\hline NDS45 & CCTATAGGATACTTAAGCCATCGAGAGGGACACGGCGAATAGCCA \\
\hline TDS45 & ATGGCTATTCGCCGTGTCCCTCTCGATGGCTGTAAGTATCCTATAGG \\
\hline TDS93* & $\begin{array}{l}\text { AGCATAATCCTGAATATGGCAAGTTACATAGATAAGTTGGTCGGTTGGG } \\
\text { GTTTGTGTGGCTTCGTCGGGCGTCTTCTACATACTACTCCTACC }\end{array}$ \\
\hline NDS96* & $\begin{array}{l}\text { GGTAGGAGTAGTATGTAGAAGACGCCCGACGAAGCCACACAAACCCCA } \\
\text { ACCGACCAACTTATCTATGTAACTTGCCATATTCAGGATTATGCTCAT }\end{array}$ \\
\hline \multicolumn{2}{|c|}{$\begin{array}{l}* \text { Reference [23] } \\
* * \text { Reference [37] }\end{array}$} \\
\hline
\end{tabular}

Table 2. Oligonucleotides used for TEC assembly 
A

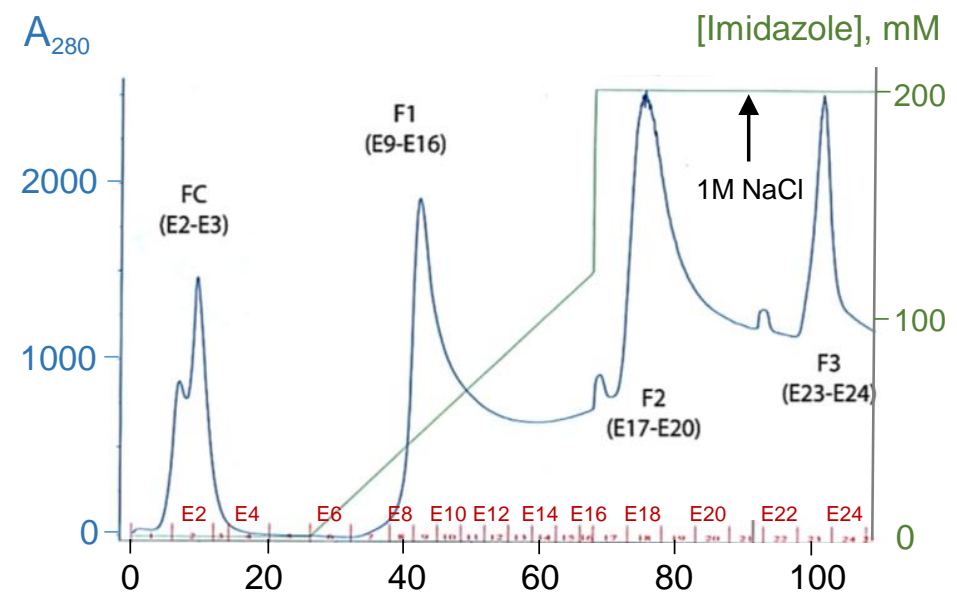

Elution volume, $\mathrm{ml}$

B

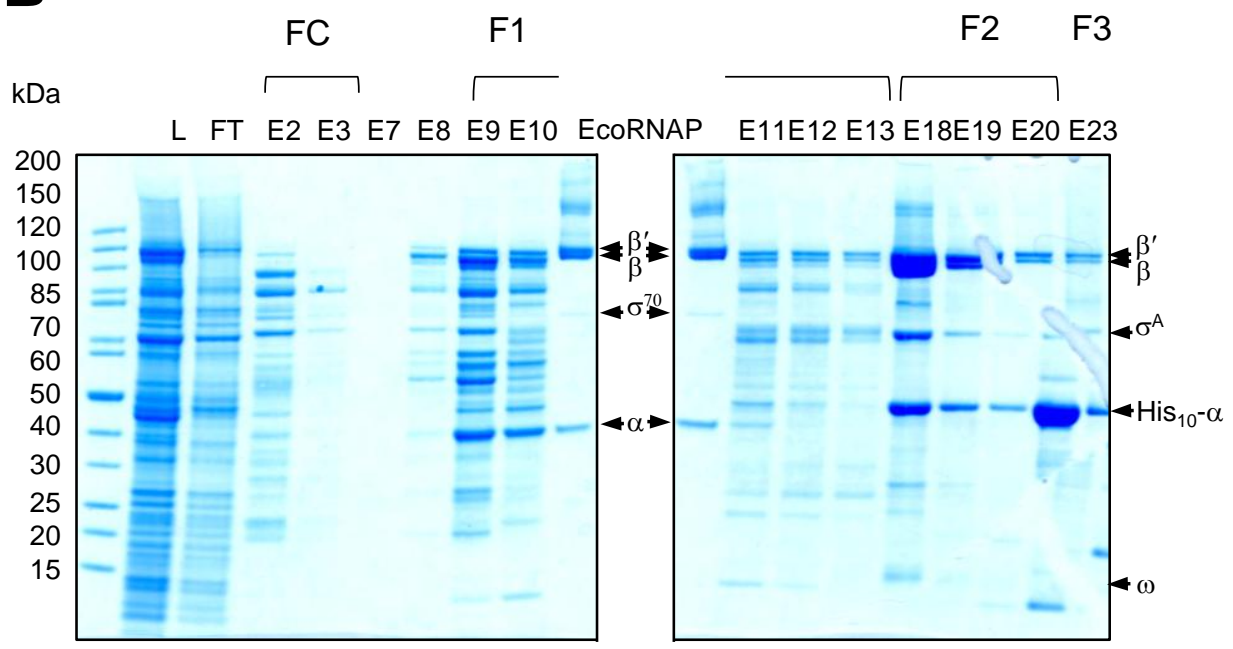


A

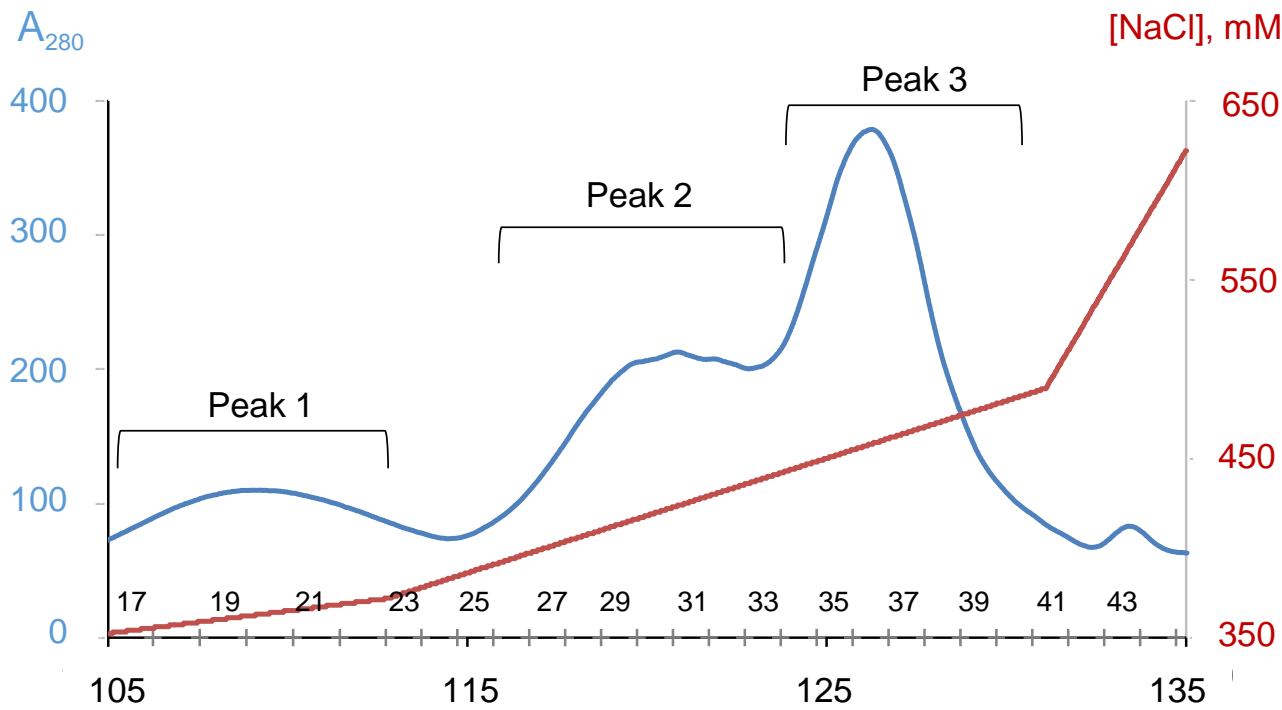

Elution volume, $\mathrm{ml}$

B

Peak 1

Peak

Peak 3

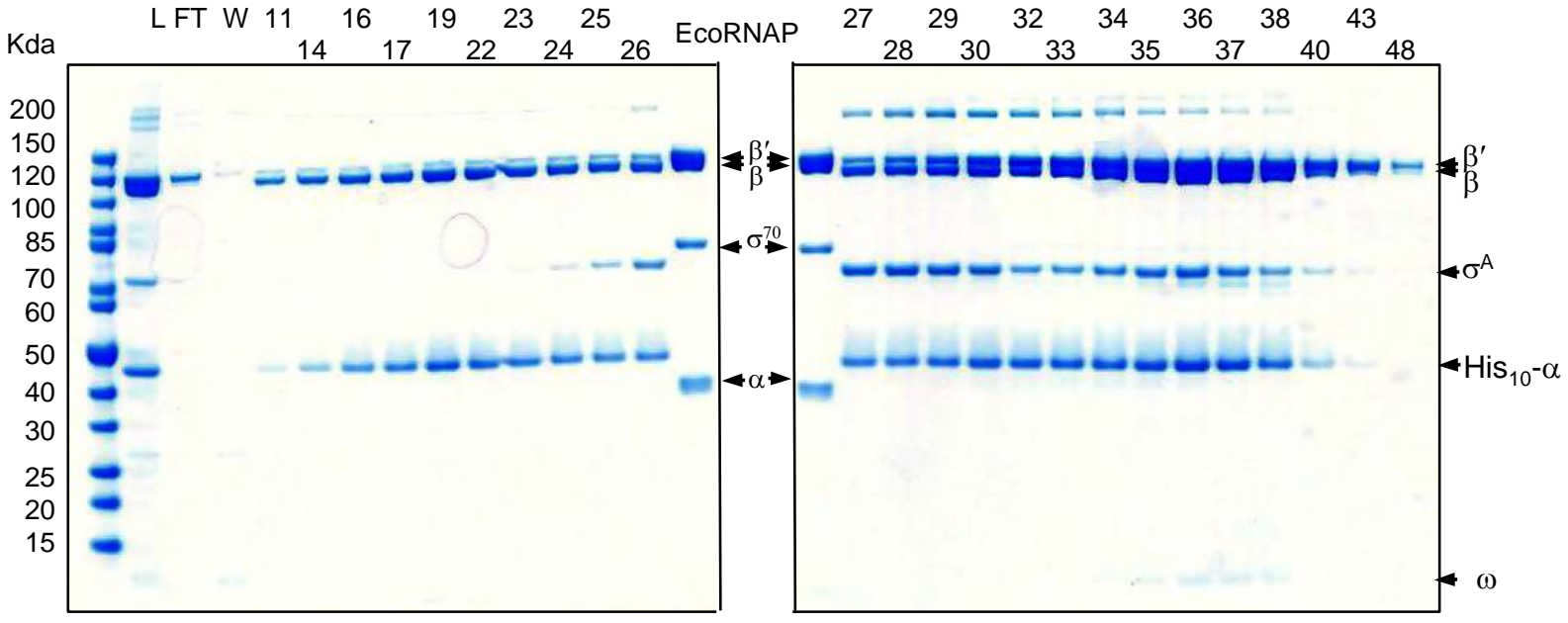

C

Time with $\longrightarrow \longdiv { 1 8 }$

$1 \mathrm{mMNTP}, \mathrm{s} 05 \rightarrow 400_{5} \rightarrow 40 \quad 05 \rightarrow 4005 \rightarrow 40$
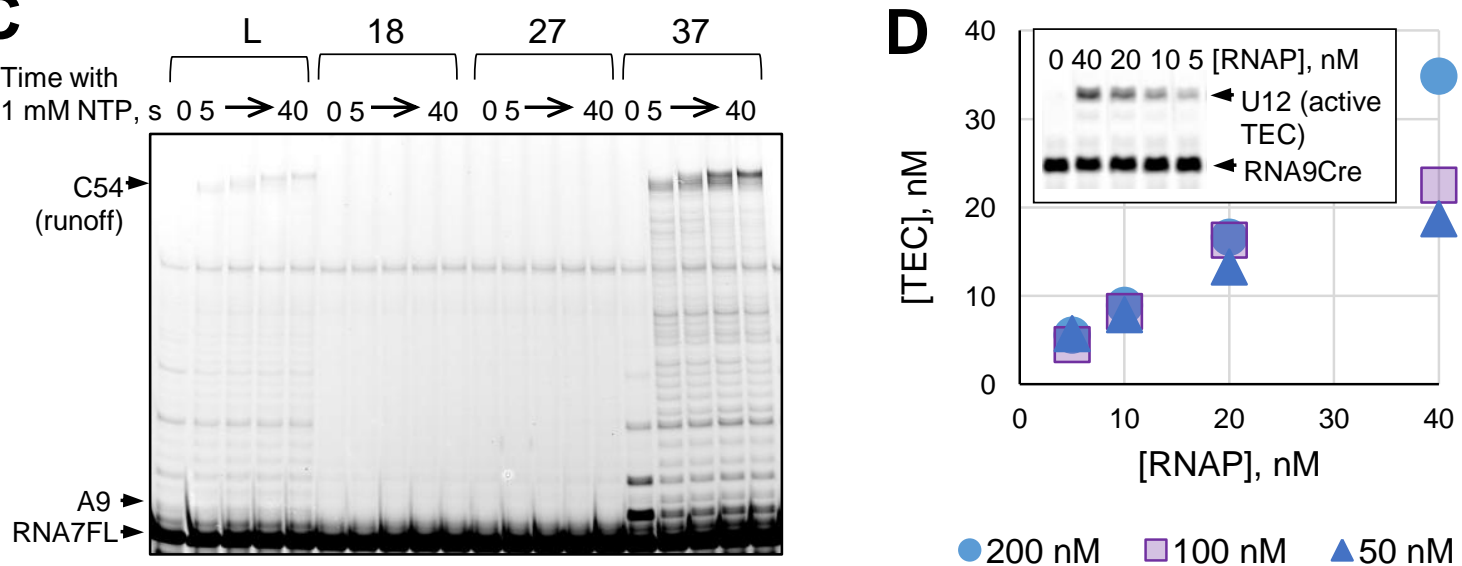

$200 \mathrm{nM} \quad \square 100 \mathrm{nM} \quad \Delta 50 \mathrm{nM}$

Herrera-Asmat et al., Figure 2 
A

MtbRNAP, RNA7FL-TDS45, ATP, GTP

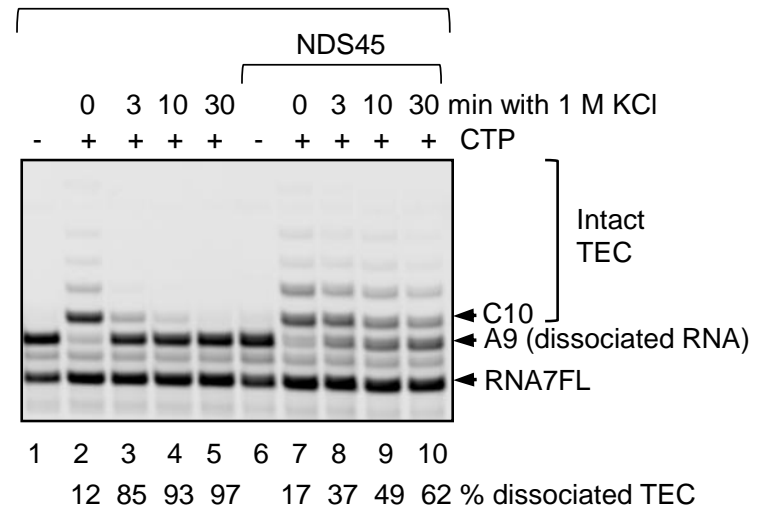

B

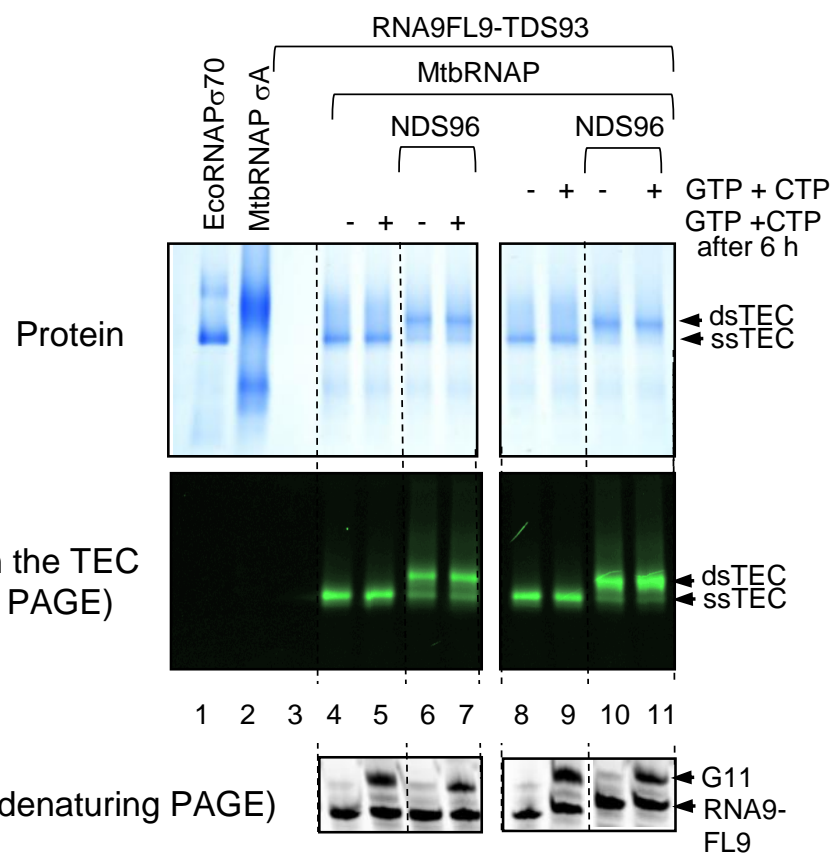

RNA in the TEC (native PAGE) 


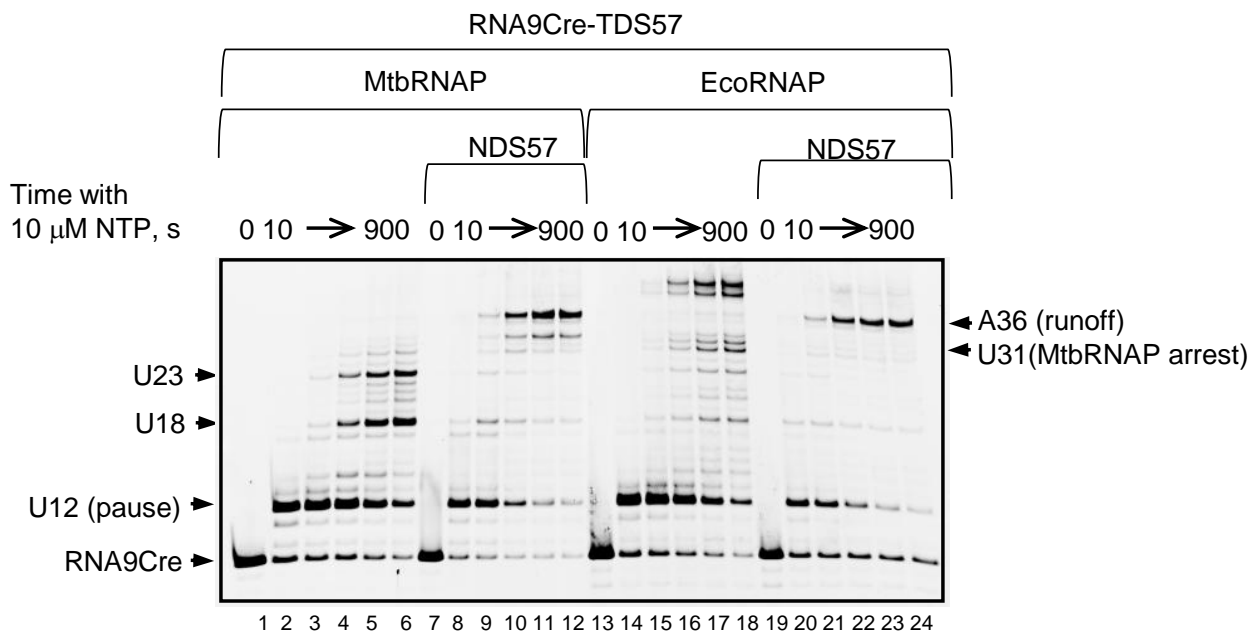

Herrera-Asmat et al., Figure 4 


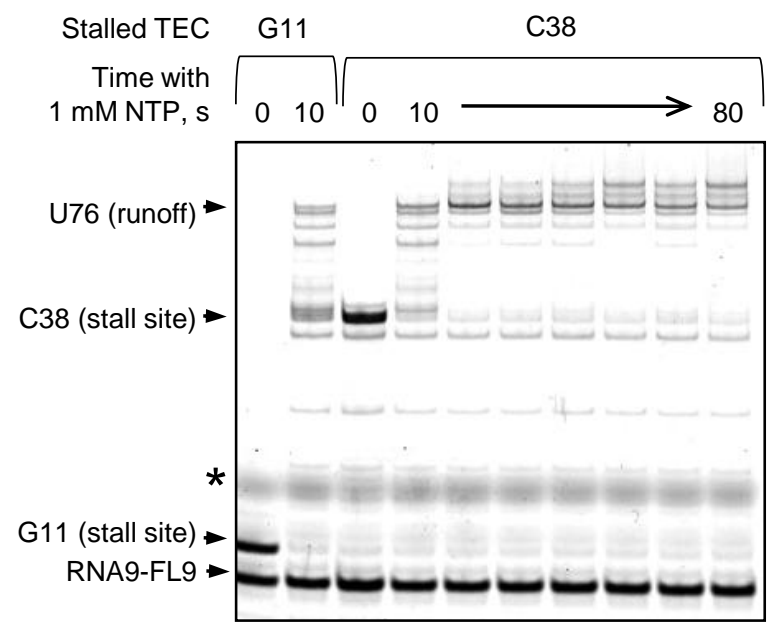

Herrera-Asmat et al., Figure 5 

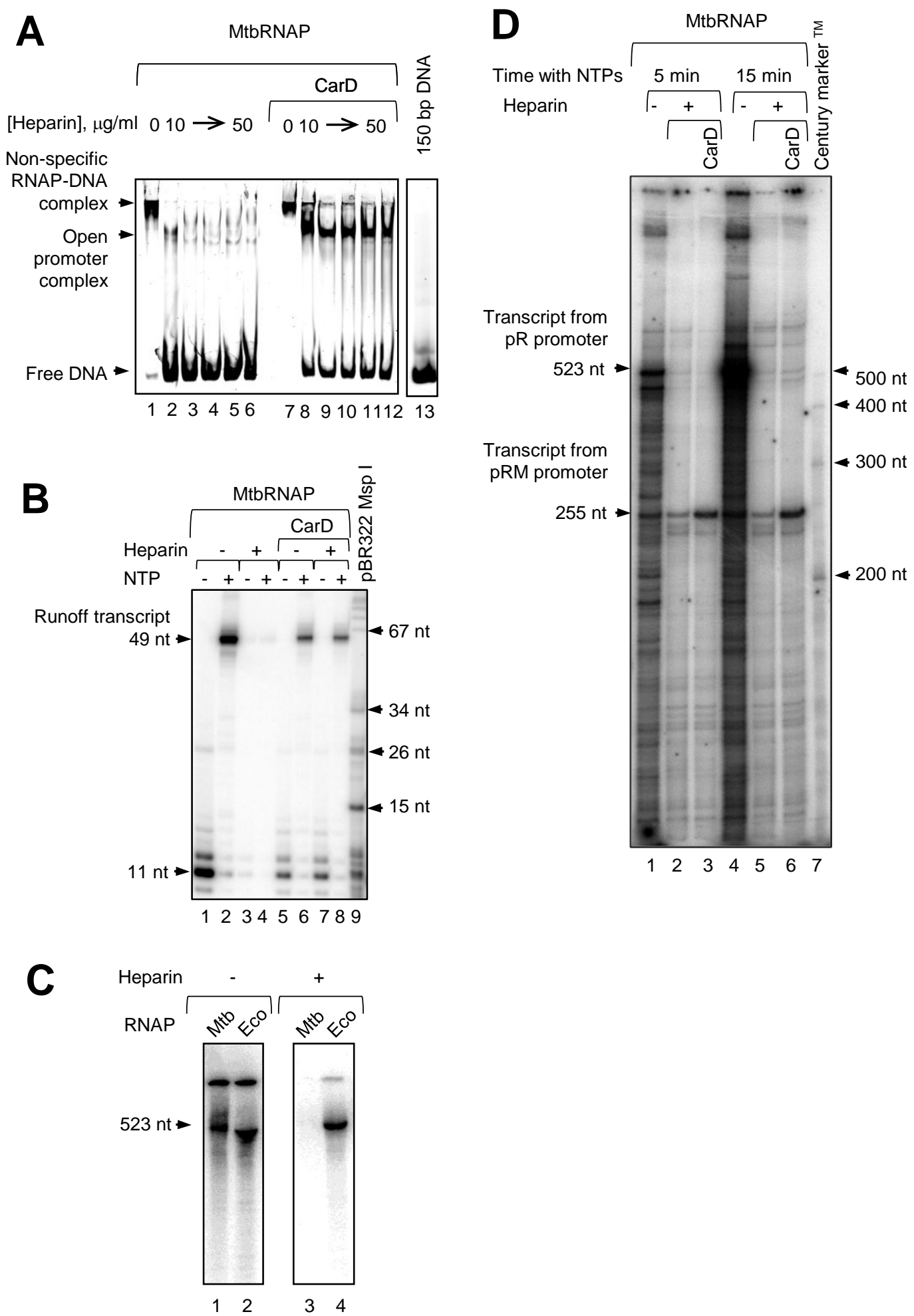